\title{
Cerambycidae (Insecta: Coleoptera) of the Parque Natural Municipal de Porto Velho, Rondônia, Western Amazon, Brazil
}

\author{
Diego de Santana Souza ${ }^{1}$ \& Alexandre de Almeida e Silva ${ }^{1,2,3}$ \\ ${ }^{1}$ Laboratório de Bioecologia de Insetos - LaBEIn, Núcleo de Ciências e Tecnologia, \\ Universidade Federal de Rondônia - UNIR, BR 364, Km 9,5, CEP 78900-000, Porto Velho, RO, Brazil, \\ www.labein.unir.br \\ ${ }^{2}$ Instituto de Pesquisas em Patologias Tropicais - IPEPATRO, Rua da Beira, 7671, BR 364, Km 3,5, \\ CEP 78912-000, Porto Velho, RO, Brazil, www.ipepatro.org.br \\ ${ }^{3}$ Corresponding author: Alexandre de Almeida e Silva, e-mail: alealsil_bio@yahoo.com.br
}

SOUZA, D.S. \& SILVA, A.A. Cerambycidae (Insecta: Coleoptera) of the Parque Natural Municipal de Porto Velho, Rondônia, Western Amazon, Brazil. Biota Neotrop. 12(1): http://www.biotaneotropica.org.br/ v12n1/en/abstract?inventory+bn01112012012

\begin{abstract}
Cerambycidae is one of the largest families of beetles and it is estimated that there are about 25,000 species of longhorned beetles in the world. However, little is known about the distribution of many species in some regions, including the Amazon. The longhorned beetles are indispensable in the ecological chain, contributing mostly to the recycling of dead wood in forest. The present study is an inventory of the Cerambycidae of the Parque Natural Municipal de Porto Velho, Rondônia, Brazil. Insects were sampled from June 2008 to May 2009 using Malaise and light traps. A total of 61 species were identified, of which 33 are new records for Rondônia and one for Amazon region, i.e., Anisopodus melzeri Gilmour, 1965.
\end{abstract}

Keywords: longhorned beetles, new records, inventory, biodiversity.

SOUZA, D.S. \& SILVA, A.A. Cerambycidae (Insecta: Coleoptera) do Parque Natural Municipal de Porto Velho, Rondônia, Amazônia Ocidental, Brasil. Biota Neotrop. 12(1): http://www.biotaneotropica.org.br/v12n1/ pt/abstract?inventory+bn01112012012

Resumo: Cerambycidae representa uma das maiores famílias de besouros e estima-se que existam cerca de 25000 espécies de Cerambycidae no mundo. No entanto, pouco se conhece sobre a distribuição geográfica de muitas espécies, conseqüência da escassez de coletas em algumas regiões, como a Amazônia. Os cerambicídeos desempenham um papel imprescindível na cadeia ecológica, contribuindo na reciclagem de madeira morta na floresta. Neste estudo, é apresentado um inventário de Cerambycidae do Parque Natural Municipal de Porto Velho, Rondônia, Brasil. As coletas foram realizadas durante o período de junho de 2008 a maio de 2009 utilizando as armadilhas Malaise e luminosa (modelo Luiz de Queiroz). Um total de 61 espécies foram identificadas, das quais 33 são novos registros para Rondônia e um para a região amazônica Anisopodus melzeri Gilmour, 1965. Palavras-chave: longicórneos, novos registros, inventário, biodiversidade. 


\section{Introduction}

Cerambycidae is one of the richest families among coleopterans and more than a 25,000 species were described worldwide (Galileo \& Martins 2006), 9,000 of these recorded to the Western Hemisphere (Monné \& Bezark 2010).

The longhorned beetles have a cosmopolitan distribution, except for the artic regions (Vives 2000). This distribution pattern is related to the vegetation and climatic characteristics of particular regions, and the Neotropical region, especially the Amazon, displays most of these insect biodiversity (Galileo \& Martins 2006).

Cerambycids have an indispensable role in the forest ecological chains due to their role in dead wood recycling. Their intimate relation with their food resources is an important feature for studies related to environmental monitoring and conservation, and also, biodiversity (Lewinsohn et al. 2005). According to Brown JR.(1991), the cerambycids have a high ecological fidelity, are highly diversified and are an important set in the ecosystems.

The Neotropical fauna of Cerambycidae is currently under study and new species have been frequently described, but there is also a lack of information and data collection from several large areas. In Brazil, some areas such as Southeast and South regions, have a good data set of the Cerambycidae fauna, but the Caatinga, Pantanal biomes and even the Amazon forest are poorly studied (Martins 1999).

In Rondônia State, only a few insect inventories can be retrieved from published data. An important contribution was provided by Monné (1990) concerning the zoological data of the influence area of the BR-364 highway construction (from Cuiabá, Mato Grosso to Porto Velho, Rondônia) and some information on the Cerambycidae fauna from 1980 to 1986 .

Fauna inventories are important tools to acquire information related to the biodiversity (Ganho \& Marinoni 2003). Besides, biodiversity studies and their data set banks contribute and guide environmental polices and plans. The present study is an inventory of the Cerambycidae fauna of the Parque Natural Municipal de Porto Velho, Rondônia, Brazilian Western Amazon.

\section{Material and Methods}

The studied area was the Parque Natural Municipal de Porto Velho (08 41' 10.26" S and 63 52' 01.98' W) forest located $14 \mathrm{~km}$ from Porto Velho downtown in Rondônia, Brazil and characterized by a lowland (less than $100 \mathrm{~m}$ ) ombrophilous open forest with palms.

Insect captures, under IBAMA license (SISBIO 19871-1), were performed from June 2008 to May 2009 using six Malaise (Townes 1972) and three light traps ("Luiz de Queiroz" model). Insect traps were set in different landscapes and environmental conditions, i.e, forest border, flooded and upperland area. The Malaise traps were monitored monthly along the year, while light traps were set once a month for a night (6:00 PM to 6:00 AM).

The longhorned beetles up to subfamily and tribe were identified using the dichotomic keys of Galileo \& Martins (2006) and species were identified using different available publications (Marques \& Napp 1996, Martins 1997, Martins \& Galileo 2006, Napp \& Monné 2006, Napp 2007, Galileo et al. 2008, Napp \& Martins, 2009). The species identification was supervised and confirmed by Dr. Ubirajara Ribeiro Martins (MZUSP). The specimens were deposited in the Entomological Collection of the Universidade Federal de Rondônia (UNIR) and in the Museu de Zoologia da Universidade de São Paulo (MZUSP).

Species distribution data is described in the catalogs of Cerambycidae (Monné 2005a,b, 2006) and other references that include species cited in Rondônia, such as Monné (1990), Napp (2007), Napp \& Martins (2009) and Monné \& Bezark (2010).

Table 1. Cerambycidae species collected in the Parque Natural Municipal de Porto Velho from June/2008 to May/2009. *New record to Rondônia; **New record to Amazonia.

Tabela 1. Espécies de Cerambycidae species coletadas no Parque Natural Municipal de Porto Velho entre Junho/2008 a Maio/2009. *novo registro para Rondônia; **novo registro para Amazônia.

\begin{tabular}{|c|c|c|c|}
\hline Family & Subfamily & Tribe & Species \\
\hline \multirow[t]{18}{*}{ Cerambycidae } & Cerambycinae & Bothriospilini & Chlorida festiva (Linnaeus, 1758) \\
\hline & & & Chlorida curta Thomson, 1857 \\
\hline & & Callichromatini & Callichroma sericeum (Fabricius, 1792) \\
\hline & & & Mionochroma vittatum (Fabricius, 1775) \\
\hline & & Clytini & Mecometopus wallacei (White, 1855) \\
\hline & & Compsocerini & Aglaoschema cyaneum (Pascoe, 1860) \\
\hline & & & Orthostoma abdominale (Gyllenhal, 1817) \\
\hline & & Dodecosini & Dodecosis saperdina Bates, 1867* \\
\hline & & Eburiini & Eburodacrys sexmaculata (Olivier, 1790) \\
\hline & & & Opades costipennis (Buquet, 1844)* \\
\hline & & Elaphidionini & Anelaphus robi Hrabovsky, 1987* \\
\hline & & & Paranyssicus conspicillatus (Erichson, 1847)* \\
\hline & & Heteropsini & Chrysoprasis abyara Napp \& Martins, 1998 \\
\hline & & Ibidionini & Compsibidion charile (Bates, 1870)* \\
\hline & & & Compsibidion maronicum (Thomson, 1867) \\
\hline & & & Gnomidolon conjugatum (White, 1855)* \\
\hline & & Rhinotragini & Odontocera furcifera Bates, 1870* \\
\hline & & & Odontocera molorchoides (White, 1855)* \\
\hline
\end{tabular}


Table 1. Continued...

\begin{tabular}{|c|c|c|c|}
\hline \multirow{9}{*}{\multicolumn{2}{|c|}{ Subfamily }} & Tribe & Species \\
\hline & & & Ommata (Agaone) notabilis (White, 1855)* \\
\hline & & & Oxylymma telephorina Bates, $1870^{*}$ \\
\hline & & Rhopalophorini & Coremia plumipes (Pallas, 1772)* \\
\hline & & & Cosmisoma argyreum Bates, 1870* \\
\hline & & Tillomorphini & Epropetes metallica Martins, 1975* \\
\hline & & Trachyderini & Batus barbicornis (Linnaeus, 1764)* \\
\hline & & & Ceragenia bicornis (Fabricius, 1801) \\
\hline & & & Sternacanthus picticornis Pascoe, $1857^{*}$ \\
\hline & Disteniinae & Disteniini & Distenia (Distenia) suturalis Bates, 1870* \\
\hline & Lamiinae & Acanthocinini & Anisopodus melzeri Gilmour, 1965** \\
\hline & & & Nyssocarinus humeralis Monné, 1985 \\
\hline & & & Nyssodrysina spreta (Bates, 1864) \\
\hline & & & Nyssodrysternum serpentinum (Erichson, 1847) \\
\hline & & & Nyssodrysternum signiferum (Bates, 1864)* \\
\hline & & & Palame anceps (Bates, 1864) \\
\hline & & & Toronaeus perforator Bates, 1864 \\
\hline & & Acanthoderini & Ateralphus senilis (Bates, 1862) \\
\hline & & & Macropophora worontzowi Lane, 1938* \\
\hline & & & Aegoschema moniliferum (White, 1855)* \\
\hline & & & Oreodera bituberculata Bates, 1861 \\
\hline & & & Oreodera undulata Bates, 1861* \\
\hline & & & Psapharochrus longispinis (Bates, 1861) \\
\hline & & Agapanthiini & Helvina lanuginosa (Bates, 1865)* \\
\hline & & & Hippopsis (Hippopsis) truncatella Bates, 1866* \\
\hline & & Anisocerini & Anisocerus stellatus Guérin-Méneville, 1855 \\
\hline & & & Gounellea bruchi (Gounelle, 1906) \\
\hline & & & Onychocerus aculeicornis (Kirby, 1818) \\
\hline & & Calliini & Drycothaea anteochracea (Breuning, 1974)* \\
\hline & & & Drycothaea ochreoscutellaris (Breuning, 1940) \\
\hline & & Colobotheini & Colobothea bisignata Bates, 1865 \\
\hline & & & Colobothea decemmaculata Bates, 1865* \\
\hline & & & Colobothea eximia Aurivillius, $1902 *$ \\
\hline & & & Colobothea macularis (Olivier, 1792)* \\
\hline & & Compsosomatini & Cristaerenea cognata (Pascoe, 1859)* \\
\hline & & Onciderini & Hesychotypa liturata (Bates, 1865) \\
\hline & & & Hypsioma sororcula Martins, $1981 *$ \\
\hline & & & Jamesia globifera (Fabricius, 1801) \\
\hline & & & Oncideres crassicornis Bates, $1865^{*}$ \\
\hline & & & Paratrachysomus huedepohli Monné \& Fragoso, 1984* \\
\hline & & & Trestonia frontalis (Erichson, 1847) \\
\hline & & Pteropliini & Ataxia obscura (Fabricius, 1801) \\
\hline & Prioninae & Callipogonini & Callipogon (Orthomegas) cinnamomeus (Linnaeus, 1758)* \\
\hline & & Mallaspini & Esmeralda laetifica Bates, $1869^{*}$ \\
\hline
\end{tabular}

\section{Results and Discussion}

A total of 171 specimens of 61 different species, mostly Cerambycinae and Lamiinae were collected during one year
(Table 1). Were recorded the subfamilies: Disteniinae and Prioninae (less than 5\%), Cerambycinae (41\%) and Lamiinae (54\%). 


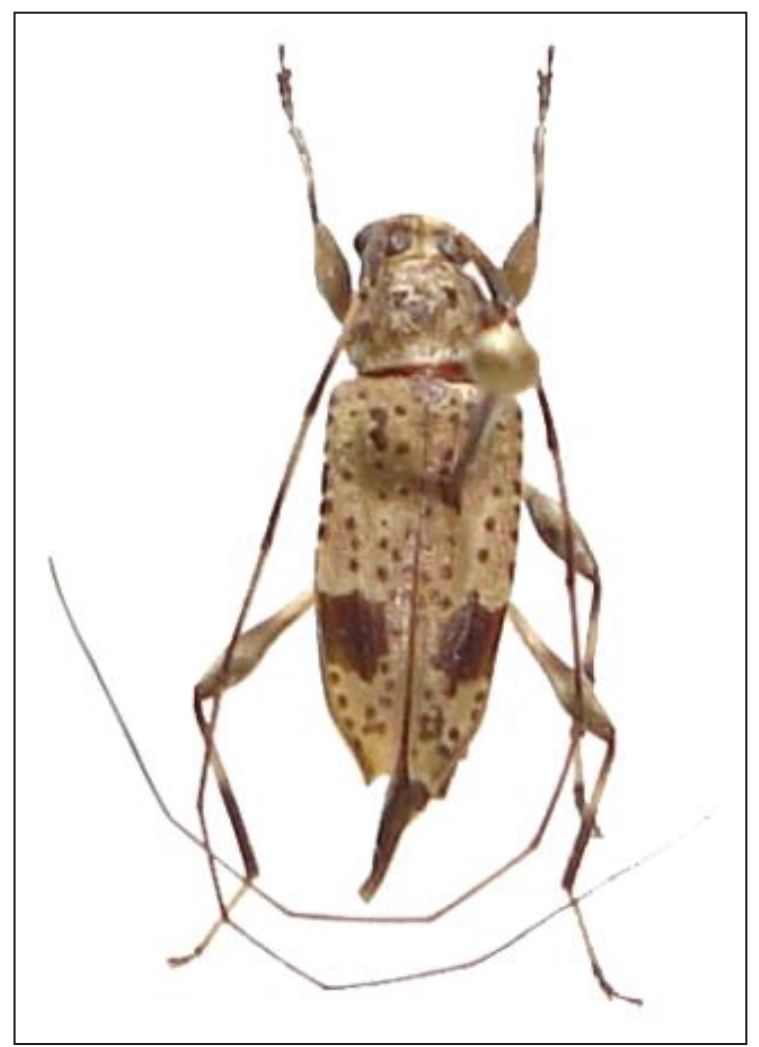

Figure 1. Anisopodus melzeri Gilmour, 1965, $8.6 \mathrm{~mm}$. Porto Velho (Parque Natural Municipal), 30.IV.2009, light trap, $08^{\circ} 41^{\prime} 02,57^{\prime \prime}$, $63^{\circ} 51^{\prime} 59$, 47 "W. (UFRO-E 73).

Among the 61 species collected, one, Anisopodus melzeri Gilmour, 1965 (Figure 1) is a new record for Rondônia and for the Amazon region and 33 species were not previously collected in Rondônia State (see asterisks in Table 1).

According to Monné \& Bezark (2010), Anisopodus melzeri was previously recorded in the Southeast and South of Brazil (Rio de Janeiro to Rio Grande do Sul) and also Bolivia Argentina.

\section{Acknowledgements}

We greatly acknowledge Dr. Ubirajara Martins (Museu de Zoologia da Universidade de São Paulo) for his careful assistance on cerambycid identification and also Anny L. Moura, Luís Felipe Daibes, Frances Tatiane T. Trindade and Sian de S. Gadelha for their help during field trips. We are grateful to the Secretaria Municipal do Meio Ambiente de Porto Velho (SEMA) that authorized the beetle captures in the Parque Municipal.

\section{References}

BROWN JR., K.S. 1991. Conservation of Neotropical environments: insects as indicators. In The conservation of insects and their habitats (N.M. Collins \& J.A. Thomas, eds.). Academic Press, London, p. 349-404.
GALILEO, M.H.M. \& MARTINS, U.R. 2006. Cerambycidae (Coleoptera, Insecta) do Parque Copesul de Proteção Ambiental, Triunfo, Rio Grande do Sul, Brasil. Museu de Ciências Naturais da Fundação Zoobotânia do Rio Grande do Sul, Porto Alegre, 314p.

GALILEO, M.H.M., MARTINS, U.R. \& MOYSÉS, E. 2008. Cerambycidae sul-americanos (Coleoptera). Museu de Zoologia da Universidade de São Paulo, São Paulo, 128p.

GANHO, N.G. \& MARINONI, R.C. 2003. Fauna de Coleoptera no Parque Estadual de Vila Velha, Ponta Grossa, Paraná, Brasil. Abundância e riqueza de famílias capturadas através de armadilhas malaise. Rev. Bras. Zool. 20(4):727-736. http://dx.doi.org/10.1590/S010181752003000400028

LEWINSOHN, T.M., FREITAS, A.V.L. \& PRADO, P.I. 2005. Conservação de invertebrados terrestres e seus habitats no Brasil. Megadiversidade. 1(1):62-69.

MARQUES, M.I. \& NAPP, D.S. 1996. Revisão e transferência para Rhopalophorini (Coleoptera, Cerambycidae, Cerambycinae) dos gêneros Coremia Audinet-Serville, 1834 e Merocoremia Marques, 1994. Rev. Bras. Entomol. 40(3-4):379-423.

MARTINS, U.R. 1997. Cerambycidae Sul-Americanos (Coleoptera). Taxonomia. Sociedade Brasileira de Entomologia, São Paulo, v. 1, 217p.

MARTINS, U.R. 1999. Cerambycidae. In Biodiversidade do Estado de São Paulo, Brasil (C.R.F. Brandão \& E.M. Cancello, eds.). FAPESP, São Paulo, p.125-132.

MARTINS, U.R. \& GALILEO, M.H.M. 2006. Gênero Hippopsis (Coleoptera, Cerambycidae, Lamiinae): chave para as espécies, sinonímia e descrição de espécies novas. Rev. Bras. Entomol. 50(4):475-487.

MONNÉ, M.A. 1990. Listas sistemáticas de Cerambycidae (Coleoptera). In Levantamento faunístico da área sob influência da BR 364 (Cuiabá Porto Velho) (M.A. Monné, org.). Conselho Nacional de Ciência e Tecnologia, Programa Polonoroeste, Brasília, p.121-176.

MONNÉ, M.A. 2005a. Catalogue of the Cerambycidae (Coleoptera) of the Neotropical Region. Part I. Subfamily Cerambycinae. Zootaxa. 946:1-765.

MONNÉ, M.A. 2005b. Catalogue of the Cerambycidae (Coleoptera) of the Neotropical Region. Part II. Subfamily Lamiinae. Zootaxa. 1023:1-760.

MONNÉ, M.A. 2006. Catalogue of the Cerambycidae (Coleoptera) of the Neotropical Region. Part III. Subfamilies Parandrinae, Prioninae, Anoplodermatinae, Aseminae, Spondylidinae, Lepturinae, Oxypeltinae, and addenda to the Cerambycinae and Lamiinae. Zootaxa. 1212:1-244.

MONNÉ, M.A. \& BEZARK, L.G. 2010. Checklist of the Cerambycidae and related families (Coleoptera) of the Western Hemisphere. 470p. http://plant.cdfa.ca.gov./byciddb/documents.html (último acesso em 14/01/2012).

NAPP, D.S. 2007. Revisão do gênero Aglaoschema Napp (Coleoptera, Cerambycidae). Rev. Bras. Zool. 24(3):793-816. http://dx.doi. org/10.1590/S0101-81752007000300031

NAPP, D.S. \& MARTINS, U.R. 2009. Tribo Callichromatini, In Cerambycidae Sul-Americanos (Coleoptera). Taxonomia. (Martins, U.R. org.). Sociedade Brasileira de Entomologia, São Paulo, v. 10, p. 223-352.

NAPP, D.S. \& MONNÉ, M.L. 2006. Novas espécies de Mecometopus Thomson (Coleoptera, Cerambycidae). Rev. Bras. Entomol. 50(1):39-42. http://dx.doi.org/10.1590/S0085-56262006000100005

TOWNES, H. 1972. A light-weight Malaise trap. Entomol. News 83:239-247.

VIVES, E. 2000. Coleoptera, Cerambycidae. In Fauna Iberica. (Ramos, E. et al. eds.) Museo Nacional de Ciencias Naturales, CSIC, Madrid, v.12, 716p. 